\section{David Tellez Maqueo}

Universidad Panamericana (Meksyk)

detellez@gmail.com

ORCID: 0000-0003-0261-4893

DOI: http://dx.doi.org/10.12775/BPTh.2020.016
Biblica

et

Patristica

Thoruniensia

13 (2020) 3: 341-355

ISSN (print) 1689-5150

ISSN (online) 2450-7059

\title{
The vice of lust and its impact on intellectual knowledge in the teachings of some fathers of the church
}

\begin{abstract}
The question I want to put forth is whether the pleasure that ensues upon lust, regardless it being moderate or excessive, is so strong that it has the power to overwhelm the mind, bringing it into a state that prevents it from approaching reality serenely, and depriving it of clarity and the mental sharpness required to make right decisions and to attain a more accurate understanding of reality. I analyze the question stating as a conclusion that according to John Chrysostom, Gregory of Nyssa, Augustine of Hippo and Gregory the Great, the regulation of sexual desire, which is proper to chastity, anthropologically predisposes the intellect to greater clarity in order to know the truth, whereas lust is unsuitable to attain this knowledge.
\end{abstract}

Keywords: Lust; Chastity; Sexual Pleasure; Desire; Knowledge.

\section{Introduction}

G. K. Chesterton says: "All healthy men, ancient and modern, Western and Eastern, hold that there is in sex a fury that we cannot afford to inflame; and that a certain mystery must attach to the instinct if it is to continue delicate and sane". ${ }^{1}$ Using his traditional, ironical language, we read the following in other of his works: "about sex especially men are born unbalanced; we might almost say men are born mad". 2 Throughout these statements, Chesterton points out the fact that every man born seems abnormal with regard to sex. As a result of a strong inclination to carnal pleasures, even some of the holiest men have expressed their concerns in regard to the constant struggle against disordered sexual desires. John Cassian reports that Basil of Caesarea used to feel disheart-

1 G.K. Chesterton, The Common Man, "The real Doctor Johnson”.

2 Idem, The Everlasting Man, "The Demons and the Philosophers". 
ened by thinking to himself: I know not a woman and yet I am not a virgin. According to Cassian, ${ }^{3}$ Basil meant that bodily purity consists not so much in foreswearing women but in the integrity of heart. On his part, Jerome talks about the casual aspect of lust when he says: "excess in eating is the mother of lust; a belly that is distended with food and saturated with draughts of wine is sure to lead to sensual passion".

These are but some examples of Christian authors who have addressed the topic of sexuality from an anthropological perspective, whose relevance is tantamount to that of Plato or Schopenhauer. Referring to all these approaches, some contemporary scholars have considered that when philosophers have addressed the topic of sexuality they have done so as if this subject were unimportant in their thinking. ${ }^{5}$ Yet, since we cannot discuss lust without addressing sexuality, we must hold that Christian philosophers were not indifferent or lacked interest in sexual desire. Nevertheless, they were certainly not driven by scientific curiosity, but by a spiritual purpose, that is, their inquiry unfolded within the broader framework of the ethical virtue to which sexual desire is ordered. This explains why the most relevant Christian thinkers regarded the virtue of chastity as important: while not an end in itself, chastity is a means ordered to a higher good, that is, love as agape. In other words, chastity was deemed important because without it there is no charity and without charity there is no holiness. ${ }^{6}$

In what follows, the question I want to put forth is whether the possession of a clean heart, as a condition of possibility to know intellectually, constitutes an anthropological constant among some Christian thinkers between IV-VI A.D. I analyze the question stating that according to John Chrysostom, Gregory of Nyssa, Augustine of Hippo and Gregory the Great, the regulation of sexual desire, which is proper to chastity, anthropologically predisposes the

3 Institutiones, VI, 19, CSEL 17, 125. To a better understanding of what "integrity of heart" means, see: D. Okholm, Dangerous Passions, Deadly Sins, p. 54.

4 Jerome, Ep. 55.2 [ad Amandum], NPNF2-VI, tr. Freemantle, p. 110. In harmony with Jerome's statement cfr. Tertullian, On Fasting, 1, ANF-IV, tr. Thelwall, p. 102: "The arrangement of a man's organs suggests the course of his vices. First, the belly; and then immediately the materials of all other species of lasciviousness are laid subordinately to daintiness: through love of eating, love of impurity finds passage".

5 W.M. Alexand, , Philosophers Have Avoided Sex, Diogenes, 72 (1970), pp. 56-74. Basing his claims on George Simmel and Erwin Reisner, the author holds that Plato's discussions in the Phaedrus or the Banquet and Schopenhauer's reflections on the subject, as well as the great classical thinkers' contributions in this regard, have distinctively attracted the attention of poets because of the link between sexuality and love.

6 J.S. Grabowski, Sex and Virtue. An Introduction to Sexual Ethics, p. 83. 
intellect to greater clarity in order to know the truth, whereas lust is unsuitable to attain this knowledge.

\section{Classical Background}

Describing lust as something that undermines the intellectual power is strange and perhaps counter-cultural for today's man, immersed in a culture dominated by the endless search for all kinds of pleasures, both natural and created. In the contemporary culture, lust has almost lost its negative connotation, to the point that it has almost been identified as a virtue, as a technique for achieving ever more refined gratification. ${ }^{7}$ Among the Fathers of the Church, however, the prevaling reality was quite another. But, what do we mean by lust in classical and christian philosophy?

In a broader sense, lust entails a sense of dissolution, a being free of any kind of bond so as to be able to freely enjoy pleasures in general and not only the sexual pleasure. This aspect is historically highlighted by Isidore of Seville, according to whom lust is defined as a "solutus in voluptates." ${ }^{\text {I }}$ Isidore links the word "lustful" to "dislocated" for, like the latter, the lustful is out of place (locus), that is, dis-located like the bone that lies disjointed before the pleasures. On the other hand, he links "libidinous" to "libero", since the former is the subject who does freely what he wants. He finally speaks of the "lascivious", which is related to "laxus", that is, the "lazy" and "loose" individual.

In a more specific sense, the one that we adopt along this paper, lust is described by Augustine of Hippo in the following terms: "Although, therefore, lust may have many objects, yet when no object is specified, the word lust usually suggests to the mind the lustful excitement of the organs of generation". And while Augustine refers to lust as anything that arouses sexual excitement

7 In this sense, see: S. Blackburn, Lust, New York, 2006: "Lust is the enthusiastic desire, the desire that infuses the body for sexual activity and its pleasures for their own sake", in: A. Mohler, Desire and Deceit. The Real Cost of the New Sexual Tolerance, Colorado Springs CO, 2008, p. 47.

Blackburn defends the use of pornography, in which the highest degree of sexual satisfaction can be achieved, and opposes the Augustinian and Senecan vision of lust as a pessimistic and vicious reality, the Taoist conception of lust as a rejuvenating and life-giving power.

8 Isidore, Etymolog., X (PL 82: 384).

9 civ. Dei, XIV, 16, NPNF1-II, tr. M. Dodds, p. 275. 
in the organs of generation, ${ }^{10}$ Aquinas will refer to it as "a disorder by reason of excess regarding desires for sexual pleasures" 11 and mainly the act of "exceeding the order and mode of reason in the matter of venereal acts." 12

The anthropological conception that lust can negatively impact one's conception of reality is framed in the classical ancient thesis that the knowledge carried out by the intellectual soul is influenced by the type of life one has developed. In the Bible it is stated that: "the wandering of concupiscence overturneth the innocent mind". ${ }^{13}$ Plato had spoken in this regard when he pointed

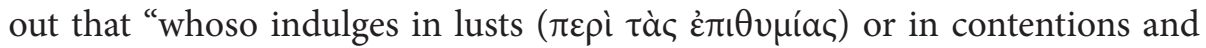
devotes himself overmuch thereto must of necessity be filled with opinions ( $\tau \grave{\alpha} \delta$ ó $\gamma \mu \alpha \tau \alpha$ ) that are wholly mortal, and altogether, so far as it is possible to become mortal, fall not short of this in even a small degree, inasmuch as he has made great his mortal part". ${ }^{4}$

Along with Plato, Aristotle recognizes the effect that pleasure can have on intellectual operations, since delectation has the power to increase attention to that which we delight in. But unlike Plato, Aristotle distinguishes between various pleasures, recognizing among them some that, far from preventing the use of reason, can actually aid it to carry out its operations with greater efficiency and diligence. This is the case of intellectual pleasures, which have a positive impact on knowledge insofar as they perfect the operation of knowing by facilitating its exercise. And so he states:

Those who work with pleasure always work with more discernment and with greater accuracy-for instance, students who are fond of geometry become proficient in it, and grasp its various problems better, and similarly lovers of music,

10 "Although, therefore, lust may have many objects, yet when no object is specified, the word lust usually suggests to the mind the lustful excitement of the organs of generation": civ. Dei, XIV, 16, NPNF1-II, tr. M. Dodds, p. 275.

11 On Evil, q. 15, a. 1, tr. R. Reagan, p. 775.

12 ST, II-II, q. 153, a. 3.

13 Wisdom, 4, 12, according to the Douay-Rheims Challoner Bible version (1752).

14 Timaeus, 90b, 1-6, Plato's Works, tr. Lamb, p. 247 Plato refers in passing to the causal aspect of concupiscence by acknowledging that the sexual organs of men and women are living forces, not to say almost independent of man himself, which would explain their rebelliousness to reason: "Wherefore in men the nature of the genital organs is disobedient and self-willed, like a creature that is deaf to reason, and it attempts to dominate all because of its frenzied lusts. And in women again, owing to the same causes, whenever the matrix or womb, as it is called - which is an indwelling creature desirous of child-bearing - remains without fruit long beyond the due season, it is vexed and takes it ill" (Timaeus, 91b4-91c3; tr. Lamb, pp. 249, 251). 
architecture or the other arts make progress in their favorite pursuit because they enjoy it. ${ }^{15}$

Notwithstanding the above, Aristotle, along with Plato, recognizes the existence of some bodily pleasures that affect the work of the intellect by affecting its capacity to know the truth in matters of practical reason, but not in matters of theoretical reason, which means that a bodily pleasure, when moderate, does not destroy judgments of a speculative nature (I think of any proposition in mathematics, such as 'the triangle has three angles equal to two straight ones'), but only warps the appreciations involved in human actions, that is, it distorts the judgment of prudence.

Since prudence is concerned with the ability to know the principles of action, which are the ends in view of which one acts and which are necessary for determining what is good for men, ${ }^{16}$ when man allows himself to be carried away by intense pleasure, the judgment of prudence can be corrupted inasmuch as man no longer sees the need to choose what prudence presented to him as something good to do in view of an end. At that moment everything is decided on the basis of what is more pleasant. This is what Aristotle means when he says that vice tends to destroy the sense of principle, ${ }^{17}$ that is, it destroys the perception of truth in regard to action.

It is noteworthy that for Aristotle bodily pleasure does not succeed in destroying a judgment of theoretical reason as long as it is a moderate pleasure. This statement, however, leads to a problem that ought to be mentioned and promptly answered, because it is a fundamental point for the thesis articulated at the beginning of this paper. Can an immoderate pleasure such as sexual pleasure-the most intense of all bodily pleasures-have at least an effect on a judgment of theoretical reason? The answer given by Aristotle is completely positive, as he later on affirms in the same work by stating that:

Pleasures are a hindrance to prudent deliberation, and the more so the more enjoyable they are; for instance, sexual pleasure: no one could think of anything while indulging in it. ${ }^{18}$

15 Nicomachean Ethics, 1175a 31, Aristotle's Works, tr. Rackham, pp. 599, 601.

16 Ibidem, 1140b 8.

17 Ibidem, 1140b 20, Aristotle's Works, tr. Rackham, p. 339: "A man corrupted by a love of pleasure...entirely fails to discern any first principle, and cannot see that he ought to choose and do everything as a means to this end, and for its sake; for vice tends to destroy the sense of principle".

18 Ibidem, 1152b 18, Aristotle's Works, tr. Rackham, p. 431. 
If no one can think of anything in the presence of sexual pleasure, then I would not be able to even think that 'the triangle has three angles equal to two straight ones. This allows us to notice the effect that a bodily pleasure-more specifically, sexual pleasure-can have on knowledge in general, whether it be practical or theoretical. If sexual pleasure can affect theoretical knowledge by preventing someone from reflecting on anything at that moment, to the extent that it precludes the consideration of the judgment 'the triangle has three angles equal to two right angles', what can then be expected of someone experiencing sexual pleasure and needs to use his or her practical reason to choose the most appropriate means to achieve an end or to make a prudent decision?

Aristotle could provide an answer to this question by pointing out that such a person would be in a "disadvantageous" cognitive condition to attain knowledge if compared to others not experiencing sexual pleasure at that moment. This answer would explain the convenience of refraining from judging relevant matters while one undergoes an extremely intense passion, such as venereal pleasure. In short, the abundance of intense sexual pleasure is not necessarily vicious but, according to Aristotle, it always affects the work of thinking.

\section{John Chrysostom and Gregory of Nyssa}

The thesis of the negative impact of lust on intellectual knowledge has its counterpart in John Chrysostom's thesis of the positive effect of chastity on knowledge. His stance on the subject draws from a principle taken from a biblical passage in which it is written: the light of thy body is thy eye: if thy eye be single, thy whole body shall be lightsome. But if thy eye be evil thy whole body shall be darksome. ${ }^{19}$ This scriptural passage of sound anthropological content points out the singleness of eye. John Chrysostom's interpretation of this passage is that he who has a simple eye, that is, a clean eye, has greater ease to preserve his body from sin and to resist carnal temptation. Conversely, he whose eyes are disturbed by lust will not resist the temptations that come upon him and are experienced in his own body. It is in this sense that it is said that "the light of thy body is thy eye" ${ }^{20}$

19 Matthew, 6, 22-23.

20 Hom. in Matth., 45.3, NPNF1-X, tr. Prevost, p. 143. Chrysostom likens the body to a ship and the eye to the pilot. Then, he asks himself: "What the profit of a ship beautifully equipped, when the pilot is sunk beneath the waves? What the advantage of a well-proportioned body, when the sight of the eyes is stricken out?". 
Although Chrysostom's interpretation is fruitful, we deem that the interpretation of another Greek commentator, that is, Gregory of Nyssa, is the one that best conveys the connection between chastity and intellectual knowledge we strive to show. For the Cappadocian Father, if there were to be an inversion in the terms of Matthew, 6, 22-23, the result would be: the light of thy eye is thy body: if thy body be clean, thy whole sight shall be lightsome. But if thy body be vicious, thy whole sight shall be in darkness. Gregory of Nyssa notices that this would also be true. In other words, it is true that "the light of your body is your eye", as Chrysostom says. But it is also true, as Gregory of Nyssa points out, that "the light of your eye is your body". This latter statement synthetizes the main focus of this article, since it captures the relationship between chastity and intellectual knowledge: that is, if the eye, which is an allegory of thought, is freed from the disordered passions, and especially if it is cleansed from the lust of the flesh which is some kind of darkness, then we would be blessed, because we would be able to see more clearly and to understand the reality of the world and man correctly. More specifically, we would gain clearer sight of what pertains to divinity. This is an aspect of utmost importance concerning the knowledge of God in Augustine of Hippo as well as in a number of authors with a Platonic background.

The following text captures Gregory de Nyssa's thought in this respect:

How can the soul which is riveted to the pleasures of the flesh and busied with merely human longings turn a disengaged eye upon its kindred intellectual light? This evil, ignorant, and prejudiced bias towards material things will prevent it. The eyes of swine, turning naturally downward, have no glimpse of the wonders of the sky; no more can the soul whose body drags it down look any longer upon the beauty above; it must pore perforce upon things which though natural are low and animal ${ }^{21} \ldots$ If a man from the atmosphere of material indulgences has the weakness of passion spreading like a film over the keen vision of his soul, all force of expression will be wasted upon him. ${ }^{22}$

The comparison is understandable. Just as the eye purified from the film is enabled to see the objects that shine brightly in the air, by the same token the soul needs purification in order to perceive the light of truth. Only through the mastery of the fleshly lust is it possible to know reality, and moreover, to know it more clearly. Whereupon, the analysis of the authors so far discussed lead to a bottom line: lust is an essential hindrance hampering intellectual knowledge.

21 On Virginity, 5. 1, NPNF2-V, tr. Moore and Wilson, p. 351.

22 Ibidem, 10. 1, NPNF2-V, tr. Moore and Wilson, p. 354. 


\section{Augustine of Hippo and Gregory the Great}

Just as Gregory of Nyssa underlines that lust prevents intelligence from understanding the divine light and the truth, this same insight is present in Augustine of Hippo. This is especially evident in those works in which one perceives the influence exerted by the Manichean dualism on his youthful thinking. It is known that among the Manicheans there is a double dualism. On the one hand, there is the cosmic dualism that has to do with God, and according to which there are two divine entities in the universe: one good and one evil. On the other hand, there is an anthropological dualism which refers to man, according to which within the human constitution there are also two principles that flow from the aforementioned cosmic dualism: a good one which is the soul, and an evil one identified with the body. Since the soul identifies with the good, and in turn the good identifies with the divine, the goal of man in this life is to transcend the evil that proceeds from the disordered passions of the body, thus favoring intellectual knowledge and God's illumination of the soul.

While most scholars agree that Augustine abandoned cosmic dualism altogether, some authors deem it debatable whether he ever lost his affinity for the anthropological dualism, ${ }^{23}$ based on Augustine's concerned view of sexual pleasure as something unsuitable $e^{24}$ and shameful even within marriage. ${ }^{25} \mathrm{Al}-$ though there is no evidence that he became obsessed with the matter, authors like Evans grant that Augustine never quite severed the lingering association

23 Cf. S. Riker, Concupiscence in Augustine and Aquinas, Albany 1993.

24 "I perceive that nothing more saps the citadel of manly strength, whether of mind or body, than female blandishments and familiarities. Therefore, if (which I have not yet discovered) it appertains to the office of a wise man to desire offspring, whoever for this reason only comes into this connection, may appear to me worthy of admiration, but in no wise a model for imitation: for there is more peril in the essay, than felicity in the accomplishment": Augustine, sol., I, 17, NPNF1-VII, tr. Ch. Starbuck, p. 543.

25 "Marriage is itself honourable in all the goods which properly appertain to it... yet, whenever it comes to the actual process of generation, the very embrace which is lawful and honourable cannot be effected without the ardour of lust (ardore libidinis)... Now, this ardour, whether following or preceding the will, does somehow, by a power of its own, move the members which cannot be moved simply by the will, and in this manner it shows itself not to be the servant of a will which commands it, but rather to be the punishment of a will which disobeys it. It shows, moreover, that it must be excited, not by a free choice, but by a certain seductive stimulus, and that on this very account it produces shame": nupt. et conc., I, 27, NPNF1-V, tr. Holmes and Wallis, pp. 274-275. 
between matter and evil. ${ }^{26}$ And since the sexual impulse comes from matter, the corresponding conclusion drawn by Augustine is the inevitable need people have for purifying the heart of low desires, since this is what enables the inner eye of man to know reality. In order to know God, above all, we need to purify the heart of all kinds of low passions, since this enables the inner eye of the intelligence to acquire its capacity to grasp the fullness of reality through contemplation, as it follows from this excerpt:

Therefore, brothers and sisters, what calls for all our efforts in this life is the healing of the eyes of our hearts, with which God is to be seen. It is for this that the holy mysteries are celebrated, for this that the word of God is preached, for this that the Church's moral exhortations are directed, those, that is, that are concerned with the correction of our carnal desires, the improvement of our habits, the renunciation of this world, not only in words but in a change of life...to help us purge that inner faculty of ours from that things that prevents us beholding God. ${ }^{27}$

Although the aforementioned purification of the heart includes the correction of our carnal desires, it is essentially aimed at beholding God: our effort to drive lust away from the soul enables us to know more perfectly, but especially to grasp those things within the realm of moral truth, as Aristotle states. Augustine alludes to this goal when he gives the following advice: "Provide the means of seeing what you love, before you try to see it". ${ }^{28}$

26 G.R. Evans, Augustine on Evil, Cambridge, 1982, p. 36. In this regard, Burnell claims that Augustine's most controversial point about the doctrine of concupiscence is his conviction that even after baptism, freed from original guilt, there remains a kind of residual concupiscence whereby moral perfection is impossible for human beings in this world based on perf. iust. XI, 28: "Who then is pure from uncleaness? Not one; even if he be an infant of only one day upon the earth" (NPNF1-V, tr. Holmes and Wallis, p. 169). See P. Burnell, Concupiscence, in: Augustine through the Ages. An Encyclopedia, p. 225; idem, The Augustinian Person, pp. 77-78.

27 Augustine, Serm. 88. 5, WSA, vol. III/3, tr. Hill, p. 422.

In other place Augustine says: "Do you want to see?...First of all give some thought to purifying the heart. Make this your business, give yourself time for this, apply yourself to this task. What you want to see is pure, but what you want to see it is impure. You are thinking of God as if he were some vast and manifold light for these eyes, you are enlarging space to yourself to your heart's content; your are not setting bounds where you don't want them, you are setting them where you do. These are all the fancies and imaginations of your heart, they are all the impurity of your heart. Remove them, throw them away. If some dust fell in your eye, and you wanted me to show you the light, your eyes would first seek something to wipe them clean. There is so much impurity, uncleanness in your heart": Serm. 261.4, WSA, vol. III/7, tr. Hill, pp. 210-211.

28 Augustine, en. Ps. 142. 5, NPNF1-VIII, tr. Tweed, p. 488. 
Concerning the resulting connection between chastity and knowledge, there are three passages that are worth considering.

A) The first one is a brief but meaningful text from the book of Confessions in which Augustine states:

I will now call to my mind my past foulness and the carnal corruptions of my soul, not because I love them, but (...) that I may love Thee, o my God (...) and recollecting myself out of that my dissipation, in which I was turn to pieces, while, turned away from Thee the One, I lost myself among many vanities. ${ }^{29}$

With these words he indicates an interesting fact in which the process of learning is involved. Lust favors distraction, an issue already addressed here by Aristotle when he states that bodily delectations have the power to make us pay great attention to the realities we enjoy. ${ }^{30}$ The same idea would be later shared by Gregory the Great (VI A.D.) by saying that: "a mind cannot think on itself, which is not entirely at home in itself. And it is unable to be entirely at home in itself, because it is hurried away by many lusts and it is distracted from itself by many objects". ${ }^{31}$ By contrast, the collected soul draws strenght and may rise to the greatest heights: "For what is a lock of the head, but the toughts of the mind gathered together, so as not to be scattered and dispersed, but to remain bound by discipline?". ${ }^{32}$

B) The second passage refers to the way lust fragments the person and can lead to the unmanageability of one's being, unlike chastity, which has the power to reintegrate the operations and faculties of the individual by conferring unity to the body, the will, the intellect, and the emotions. Bound up with this unmanageability, Augustine describes the untimeliness with which sexual desire suddenly arises while unintended by the will, for example, when keeping sexual continence is required, or the other way around, when the sexual impulse does not comply with the will when it is required to appear. Augustine refers to this lack of self-mastery when he states: "even those who delight in this pleasure are not moved to it at their own will (...): sometimes this lust importunes them

30 Aristotle, Nicomachean Ethics, 1175a 31.

31 Gregory the Great, Morals, XXXI, 12, 18, tr. J. Bliss, p. 440.

32 Ibidem, p. 440. 
in spite of themselves, and sometimes fails them when they desire to feel it, so that though lust rages in the mind, it stirs not in the body". ${ }^{33}$

In this way, although it is more often the case that lust opposes the soul that resists it, sometimes lust is divided against oneself when it moves the soul but leaves the body unmoved. Such division brought about by lust illustrates the aforementioned fragmentation.

C) Finally, the third passage comes from the City of God. While discussing other anthropological effects that lust inflicts on the person, Augustine points out one vital aspect: when sexuality is affected, the whole person is affected. This is what he means when he claims:

Lust not only takes possession of the whole body and outward members, but also makes itself felt within, and moves the whole man with a passion in which mental emotion is mingled with bodily appetite, so that the pleasure which results is the greatest of all bodily pleasures. So possessing indeed is this pleasure, that at the moment of time in which it is consummated, all mental activity is suspended. ${ }^{34}$

Therefore, when lust reaches the peak of intensity, the reason is indeed obscured in the sense that the darkness arises in thought, and so there is no doubt that lust affects the work of thinking by suspending the intellectual power based on Aristotle's stance ${ }^{35}$ But at the same time occurs, based on Augustine, that when lust does not get its climax, awareness is not completely incapable of thinking at all. As it is stated by him further, lust almost reduces its sharpness ("quasi vigilia cogitationis obruatur") ${ }^{36}$ making this way the spirit less brilliant. In all cases, from the augustinian viewpoint, the more is the intensity of lust, the more is the lack of awareness.

While we have already mentioned when discussing distraction, Gregory the Great's thought is of utmost importance since, he identifies, along with Augustine, the possibility of chastity giving unity to the cognitive operations that lust had the power to fragment. Chastity strengthens the full focus of the will on what is truly relevant, such as the spiritual progress that comes from the previous intellectual identification of personal vices, in order to achieve the complete eradication of one's own miseries. He explains this by posing the example of the saints:

33 Augustine, civ. Dei, XIV, 16, NPNF1-II, tr. M. Dodds, p. 276.

34 civ. Dei, XIV, 16, NPNF1-II, tr. M. Dodds, p. 275.

35 Ethica Nicomachea, 1152b 18.

36 De civitate Dei, XIV, 16, [in:] Migne (1845): 424-425. 
Whence the mind of the just, because it is restrained, by the guardianship of discipline, from the shifting desire of all visible objects, is compacted in itself and inwardly entire; and it fitly beholds how it should conduct itself towards God, or its neighbour, because it leaves nothing of its own without, and the more it is withdrawn and restrained from outward objects, the more is it increased and kindled within; and the more it burns, the more brightly does it shine for the detection of vices. ${ }^{37}$

Gregory's thought is also remarkable for its causal explanation of lust based on the intellectual motivations of those who are tempted to indulge in it. His argument is that lust is born from certain motivations lying beneath the mind under the appearance of truth until it gets confused. ${ }^{38}$ Another aspect what explains to a certain extent lust's causality has to do with the connection he establishes between lust and gluttony. ${ }^{39}$ The assertion that lust is born of gluttony will become a recurrent feature of Christian moral philosophy in other Fathers of the Church. In this regard, Jerome states that: "the eating of flesh, and drinking of wine, and fulness of stomach is the seed-plot of lust". ${ }^{40}$ Tertullian shares a similar opinion when he states that "lust without voracity are so united and concrete, that, had there been any possibility of disjoining them, the pudenda would not have been affixed to the belly itself rather than elsewhere" 41 as well as Augustine when he claims: "if the soul is weighed down by too much food, the man becomes torpid, and there will spring up thorns of wicked desires". ${ }^{2}$ And Gregory's position stands in tune with all these authors in saying that lust originates from the consumption of excessive food. Likewise, Gregory is known by his reference to the moral consequences of these carnal vices, better known as

37 Gregory the Great, Morals, XXXI, 12, 19, tr. J. Bliss, p. 440.

38 "Lust also is wont to exhort the conquered heart, as if with reason, when it says, «Why enlargest thou not thyself now in thy pleasure, when thou knowest not what may follow thee?», «Thou oughtest not to lose in longings the time thou hast received; because thou knowest not how speedily it may pass by», "For if God had not wished man to be united in the pleasure of coition, He would not, at the first beginning of the human race, have made them male and female»": ibidem, XXXI, 45, 90, tr. J. Bliss, p. 492.

39 "But it is plain to all that lust springs from gluttony, when in the very distribution of the members, the genitals appear placed beneath the belly. And hence when the one [belly] is inordinately pampered, the other [genitals] is doubtless excited to wantonness": ibidem, XXXI, 45, 89, tr. J. Bliss, p. 491.

40 Against Jovinianus, II, 7, NPNF2-VI, Freemantle, p. 394. Using a poetic expression taken from Terence's Eunuch (4.5.6), Jerome says: "Venus shivers unless Ceres and Bacchus be with her".

41 On Fasting, 1, ANF-IV, tr. Thelwall, p. 102.

42 Serm. 141.1 (PL 39, 2020), in: Alphonsus de Liguori, Ascetical Works, p. 375. 
the daughters of gluttony and lust. ${ }^{43}$ Whereas the person who governs his carnal passions generates a special predisposition of the intellect for an adequate knowledge of the truth, the daughters of gluttony and lust provoke a negative impact on the righteous judgment of prudence, and "a disharmony element in the human action". ${ }^{44}$ All these matters would greatly influence Thomas Aquinas' anthropological explanation concerning both capital vices in the thirteenth century. But Aquinas's consideration of the issue would demand a further discussion that surpasses what we have purposed here.

\section{Conclusion}

In this article I have outlined the existence of an historical constant that is repeated among some Christian thinkers between the fourth and sixth centuries A.D., to wit, the negative impact that venereal pleasure has on the knowledge of reality. In spite of the negative consequences that lust gives rise to, it would be inaccurate to draw the conclusion that their thought is affected by some kind of Manichaeism. Firstly, because Manichaeism is contrary to the Christian thought they all professed; secondly, because the negative side of lust does not stem from following sexual pleasure-which is good in itself-but from the darkness it produces in the act of understanding. In other words, the destructiveness of lust is rather based on the fact that lust desensitizes human intelligence, inhibiting its perception of the totality of what actually exists.

Speaking from a purely anthropological standpoint (that is, without considering the morality of the ends towards which the sexual appetite ought to be ordered), the pleasure that ensues upon lust, regardless it being moderate or excessive is so strong that it has the power to overwhelm the mind, bringing it into a state that prevents it from approaching reality serenely, while also depriving it of clarity and the mental sharpness required to make right decisions and to attain a more accurate understanding of reality. Purity as a virtue does

43 "From gluttony are propagated foolish mirth (inepta laetitia), scurrility (scurrilitas), uncleanness (immunditia), babbling (multiloquium) and dullness of sense (hebetudo sensus) in understanding. From lust are generated blindness of mind (caecitas mentis), inconsiderateness (inconsideratio), inconstancy (inconstantia), precipitation (precipitatio), self-love (amor sui), hatred of God (odium Dei), affection for this present world (affectus presentis saeculi), but dread or despair of that which is to come (desperatio futuri) ": Morals, XXXI, 45,88 , tr. J. Bliss, p. 490.

44 J. Noriega, "Armonia nel motus in Deum e asimmetria: il caso delle figlie della lussuria," Divus Thomae, CXXI-3 (2018), pp. 104-5. 
not equate to puritanism but, in the words of Gregory of Nyssa, to simplicity or singleness of eye.

Putting aside the effect lust can have on willpower (a question we have not discussed here), it distinctly compromises the ability to know the higher realities, that is, the spiritual and divine ones, a fact clearly recognized by both Gregory of Nyssa and Augustine of Hippo. The latter's remarks prove to be of great relevance, since they highlight the role of chastity to reintegrate the operations of the individual, conferring unity to the functions of the body, the will, the intellect, and the emotions, thereby freeing the individual from the harm caused by a fragmented mind when falling prey to carnal or even worldly desires ("lust" and "luxury" come from the same Latin root luxus: excess, extravagant living, profusion). On his part, Gregory the Great clearly displays the influence of lust over the mind to bring about temptation, by prompting the intellectual motivations that lead men to justify their giving themselves over to sexual pleasure, thereby supporting Aquinas's well-known premise according to which we easily accept what we desire (ST I-II, q. 63, a. 3).

In light of all these concepts, the opposite of lust, that is, chastity, far from being an anachronism would be a condition for recognizing truth, as will be seen more overtly in Thomas Aquinas who, based on Aristotle, will make of sexual pleasure and its connection with practical reason the objective of a more profound analysis of the relationship between lust and intellectual knowledge.

\section{References}

Alexander, W. M., Philosophers Have Avoided Sex, Diogenes, 72 (1970), pp. 56-74. Alphonsus de Liguori, Ascetical Works, vol. XII, New York-Cincinnati-Chicago 1889. Aristotle, Aristotle's Works, Vol. 19: Nicomachean Ethics, tr. H. Rackham, New York \& London 1934.

Augustine of Hippo, City of God [civ. Dei], NPNF1-II, tr. M. Dodds, Peabody MA 1995. Augustine of Hippo, Soliloquies [sol.], NPNF1-VII, tr. Ch. Starbuck, Peabody MA 1995. Augustine of Hippo, On Marriage and Concupiscence [nupt. et conc.], NPNF1-V, tr. P. Holmes and R.E. Wallis, Peabody MA 1995.

Augustine of Hippo, On man's perfection in rightousness [perf. iust.], NPNF1-V, tr. P. Holmes and R.E. Wallis, Peabody MA 1995.

Augustine of Hippo, Sermons, WSA (=Works of Saint Augustine), Sermons On the New Testament, vol. III/3 (serms. 51-94), tr. E. Hill, Brooklyn, New York 1991.

Augustine of Hippo, Sermons, WSA, Sermons On the Liturgical Seasons, vol. III/7 (serms. 230-272B), tr. E. Hill, Brooklyn, New York 1993.

Augustine of Hippo, Expositions On the Book of Psalms [en. Ps.], NPNF1-VIII, tr. J.E. Tweed, Peabody MA 1995. 
Augustine of Hippo, Confessions [conf.], NPNF1-I, tr. J.G. Pilkington, Peabody MA 1995.

Aurelii Augustini, De civitate Dei contra Paganos, in: Migne, J.P. (ed.), Patrologia, series latina [PL], vol. XLI, tomus VII, Paris 1845.

Aurelii Augustini, Sermones suppositii, in: Migne, J.P. (ed.), Patrologia, series latina, vol. XXXIX, tomus V, pars altera, Paris 1845.

Burnell, P., Concupiscence, in: Augustine through the Ages. An Encyclopedia, A. Fitzgerald (ed.), Cambridge 1999.

Burnell, P., The Augustinian Person, Washington D.C. 2005.

Cassiani, Iohannis, Opera, CSEL [=Corpus Scriptorum Ecclesiasticorum Latinorum], vol. XVII, pars 1, Vindobonae 1888.

Chesterton, G.K., The Everlasting Man, London, 1925, available at: URL= http://www. gkc.org.uk/gkc/books/everlasting_man.html\#chap-I-vi [accessed 23.03.2020]

Chesterton, G.K., The Common Man, New York, 1950, available at: URL= http://www. gkc.org.uk/gkc/books/Common_Man.html\#johnson [accessed 21.03.2020].

Douay-Rheims Challoner Bible, https://www.bible.com/es/versions/55-drc1752-douay-rheims-challoner-revision-1752 [accessed Sept. 22, 2020].

Evans, G.R., Augustine on Evil, Cambridge 1982.

Grabowski, J.S., Sex and Virtue. An Introduction to Sexual Ethics, Washington D.C. 2003.

Gregory of Nyssa, On Virginity, NPNF2-V, Ascetic and Moral Treatises, tr. W. Moore and H. Wilson, Peabody MA 1995.

Gregory the Great, Morals On the Book of Job, vol. III/2, Bk. XXX-XXXV, tr. J. Bliss, Oxford 1850.

Isidori Hispaliensis, Etymologiarum Libri XX, in: Migne, J. P. (ed.), Patrologiae, series latina, vol. LXXXII, tomi III-IV, Paris, 1850.

Jerome, Epistles, in: NPNF2-VI (=Nicene and Post-Nicene Fathers), tr. Freemantle, Peabody MA 1995.

John Chrysostom, Homilies on the Gospel of St. Matthew, NPNF1-X, tr. G. Prevost, Peabody MA 1995.

Mohler, A., Desire and Deceit. The Real Cost of the New Sexual Tolerance, Colorado Springs CO, 2008.

Noriega, J., Armonia nel motus in Deum e asimmetria: il caso delle figlie della lussuria, Divus Thomae, CXXI/3 (2018), pp. 104-5.

Okholm, D., Dangerous Passions, Deadly Sins. Learning from the Psychology of Ancient Monks, Grand Rapids, MI 2014.

Plato, Works, Vol. 9: Timaeus, tr. W.R.M. Lamb, Cambridge (MA) \& London 1925.

Riker, S., Concupiscence in Augustine and Aquinas, Albany 1993.

Tertullian, On Fasting, ANP (=Ante-Nicene Fathers), vol. IV, tr. S. Thelwall, Peabody MA 1995.

Thomas Aquinas, Summa Theologiae [ST], Lander, WY 2012

Thomas Aquinas, On Evil, Oxford, 1974. 